DOI: $10.21802 /$ artm.2020.1.13.92.

УДК 616-08+615.22+616.12-005.4+616.12-089

\title{
ВПЛИВ ІНГІБІТОРА ІF-КАНАЛІВ СИНУСОВОГО ВУЗЛА НА ПЕРЕБІГ СТАБІЛЬНОЇ ІХС Й НЕЙРОГУМОРАЛЬНУ РЕГУЛЯЦІЮ СУДИН У ХВОРИХ ПІСЛЯ ВНУТРІШНЬОСУДИННОЇ КОРОНАРНОЇ АНГІОПЛАСТИКИ
}

\author{
І.Г. Купновицька, Н.М. Романишин
}

Івано-Франківський наиіональний медичний університет, кафедра клінічної фармакології і фармакотерапії, м. Івано-Франківськ, Україна,

ORCID ID: 0000-0002-0243-2638, e-mail: neliaromanyshyn@gmail.com

Резюме. Щорічно захворювання серцево-судинної системи зумовлюють 4,3 млн. смертей в Європі, що становить 48 \% від загальної смертності. Близько половини випадків летальності з них припадає на ішемічну хворобу серця (IXC). На сьогодні відомо, що в патогенезі IXC важливе місце посідають ендотеліальна дисфункція (ЕД), оксидантний стрес, дисліпідемія, системна імунозапальна активація. Запальні процеси відіграють важливу роль у процесі формування як самої атеросклеротичної бляшки, так і пошкодження нестабільної атероми 3 подальшою тромботичною оклюзією і розвитком серцево-судинних ускладнень. Метою дослідження було дослідити вплив івабрадину на клінічний перебіг захворювання, ендотеліальну функцію й показники імунозапальної відповіді організму хворих на стабільну IXC після реваскуляризації міокарда протягом 12 місяців лікування. Об’єктом дослідження обрано 120 хворих на стабільну IXC: стенокардію напруги функціонального класу (ФК) III із серцевою недостатністю (СН) IIA ФК III зі збереженою фракцією викиду лівого шлуночка (ФВ ЛШ), котрим проводили стентування КА. Обстежувані хворі рандомізовані за кількістю уражених коронарних артерій (КА) способом лікування. Івабрадин сприяє позитивній достовірній динаміці рівня ендотеліну-1 (ЕТ-1) протягом спостереження у пацієнтів з стабільною IXC після комплексного кардіохірургічного та медикаментозного лікування. Показники імунозапальної реакції та системного запалення - вміст фактора некрозу пухлин-а (ФНП-а) та С-реактивного білка (СРБ) у сироватці крові достовірно знижувалися на 6-й та 12-й місяці після лікування на відміну від контрольної групи (базова терапія), де дані показники були стабільними тільки до 6-го місяця фармакотерапії ( $<00,05)$.

Ключові слова: івабрадин, ішемія міокарда, коронарні артерії, стентування, цитокіни.

Вступ. Неінфекційні хвороби є одним із основних викликів розвитку людства у XXI столітті і створюють загрозу для соціально-економічного добробуту в усьому світі [1]. Чільне місце серед них посідають серцево-судинні захворювання, які за показниками захворюваності, поширеності, спричиненої ними первинної інвалідизації та смертності, особливо в осіб працездатного віку, протягом останніх десятиліть впевнено утримують лідерство в більшості країн, зокрема й в Україні $[4,5]$. Хронічна ішемія міокарда призводить до прогресуючого зменшення функціонального коронарного резерву, глибоких морфологічних змін серця, що клінічно проявляється зниженням толерантності до фізичного навантаження (ФН) та погіршенням якості життя (ЯЖ) і $є$ причиною розвитку гострих коронарних подій, які мають високий показник летальності за умов невчасного та недостатньо ефективного підібраного лікування [16].

На сьогодні відомо, що в патогенезі IXC важливе місце посідають такі біохімічні та патофізіологічні порушення, як ендотеліальна дисфункція (ЕД), оксидантний стрес, дисліпідемія [2, 7]. Запальні процеси займають важливе місце у процесі формування як самої атеросклеротичної бляшки, так і пошкодження нестабільної атероми 3 подальшою тромботичною оклюзією і розвитком серцево-судинних ускладнень [3, 12]. Проспективні дослідження PREVEND (Prevention of Renal and Vascular Endstage Disease) свідчать, що високий рівень С-реактивного білка (СРБ) плазми достовірно і незалежно пов'язаний 3 ризиком розвитку інфаркту міокарда (IM), інсульту й ураженням периферичних артерій як у здорових осіб, так і уражених атеросклерозом [10]. СРБ $є$ визнаним маркером напруженості гострого запального процесу, учасником запалення при атеросклерозі, асоціюється 3 частотою індукованої ішемії міокарда та визначає прогноз у хворих зі стабільним перебігом IXC [4], а фактор некрозу пухлин- $\alpha$ (ФНП-а) залишається єдиним прозапальним цитокіном, що відноситься до групи маркерів гострих форм IXC, рівень якого зростає при некрозі кардіоміоцитів [11]. Збільшення рівнів циркулюючих прозапальних цитокінів $є$ предикторами виникнення смерті у хворих 3 прогресуючою IXC $[9,12]$.

На сьогоднішній день з'ясовано можливі шляхи медикаментозної корекції ЕД та порушень імунозапальної активації у хворих на стабільну IXC, однак вони потребують подальшого всебічного вивчення та оцінки. Експериментально та клінічно доведено, що речовини, які регулюють судинний тонус, володіють також багатьма іншими ефектами, що необхідно обов'язково враховувати при проведенні відповідної терапії $[7,13]$.

Така складна ситуація зумовлює потребу пошуку нових і вдосконалення наявних способів лікування IXC. 
Обгрунтування дослідження. У ході дослідження підібрати оптимальну схему медикаментозного лікування пацієнтам із стабільною IXC після стентування КА з метою досягнення більш економної роботи серця через зменшення ЧСС, підвищення толерантності до фізичного навантаження $(\Phi Н)$, мінімізувати потребу в додатковому вживанні короткодіючих нітратів, зниження та наближення за значенням до здорових осіб рівнів ЕТ-1 та імунозапальної активності. Розробити схему комплексного, патогенетично обгрунтованого лікування хворих на стенокардію напруги після внутрішньосудинної коронарної ангіопластики 3 урахуванням динаміки надмірної ЧСС та можливості їі утримання на цільових рівнях.

Метою нашого дослідження було оцінити вплив івабрадину на перебіг стабільної IXC, показники імунозапальної відповіді та функціонування ендотелію у хворих після стентування коронарних артерій (КА) протягом 12 місяців терапії.

Методи дослідження. Об'єктом дослідження обрано 120 хворих на стабільну IXC: стенокардію напруги функціонального класу (ФК) III $з$ серцевою недостатністю (CH) IIA ФК III із збереженою фракцією викиду лівого шлуночка (ФВ ЛШ), яким проводили стентування КА. Обстежувані хворі рандомізовані за кількістю ураженних КА способом лікування. Серед обстежених переважали чоловіки - 101 особа $(84,2 \%)$. Середній вік хворих становив $61,4 \pm 0,5$ року. Групу контролю норми склали 15 практично здорових осіб зі збереженням гендерних та вікових пропорцій.

До основної групи (ОГ) увійшли 58 хворих, котрі разом з базовим лікуванням згідно з уніфікованим клінічним протоколом надання первинної, вторинної (спеціалізованої) та третинної (високоспеціалізованої) медичної допомоги «Стабільна ішемічна хвороба серця» 02.03.2016 № 152 (зі змінами 23.09.2016 № 994), рекомендацій Асоціації кардіологів України з діагностики та лікування хронічної СН (2017) приймали івабрадин (Кораксан, «Servier»,

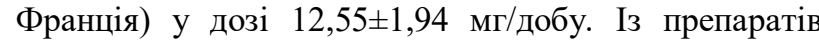
базової терапії (БТ) пацієнти вживали кислоту ацетилсаліцилову у дозі 75 мг/добу, клопідогрель 75 мг/добу, бісопролол 2,5 мг/добу, раміприл у дозі $8,61 \pm 2,85$ мг/добу або лозартан 84,62 24,02 мг/добу,

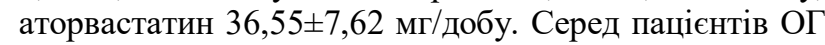
зафіксовано 15 з одно- та 43 із кількасудинним ураженням КА.

До контрольної групи (КГ) увійшли 62 пацієнти, котрим здійснили черезшкірне коронарне втручання (ЧКВ) із стентуванням КА та призначили препарати БТ, а саме препарати кислоти ацетилсаліцилової у дозі 75 мг/добу, клопідогрель 75 мг/добу, бісопролол 7,56 $\pm 2,53$ мг/добу, раміприл у дозі 5,90 $\pm 2,58$

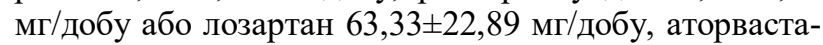

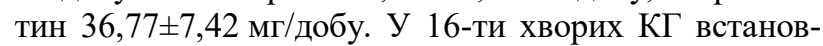
лено ураження однієї КА, у 46-ти - кількасудинне коронарне ураження.

Усім хворим до ЧКВ через 6 та 12 місяців після стентування КА та запропонованого медикаментозного лікування проводилося клінічне обстеження, що включало збір скарг та визначення потреби в до- датковому вживанні таблеток нітрогліцерину на тиждень, рівня артеріального тиску (АТ) та частоти серцевих скорочень (ЧСС) без застосування ЧССзнижуючої та гіпотензивної терапії, визначали ФК стенокардії напруги за допомогою велоергометрії (BЕМ), вміст ендотеліну-1 (ЕТ-1), ФНП- $\alpha$ та СРБ у сироватці крові.

Тривалість стабільної IXC була однаковою в обох групах спостереження і складала у 38-ми (65,5 \%) та 39-ти (62,9\%) хворих ОГ та КГ, відповідно, від 5-ти до 10 -ти років, у 25-ти (20,8 \%) пацієнтів обох груп - більше 10-ти років.

У структурі факторів ризику (ФР) у хворих найчастіше зустрічались артеріальна гіпертензія (АГ) - у 88,3 \% хворих, дисліпідемія - у 83,3 \% пацієнтів, паління - у 76,6 \% обстежених, нервово-емоційні стреси - у 70,8 \%, генетична схильність - у 54,2\%. 3 меншою частотою констатовано ожиріння - у 24,2 \%, передожиріння (гладкість) - у 57,5 \% осіб, компенсований цукровий діабет (ЦД) 2 типу - у 15,8 \%. Перенесений в анамнезі інфаркт міокарда (IM) визначили у 45,8 \% хворих, повторний (двічі) IM - у 5,8 \% пацієнтів. Частота та поширеність супутньої патології, окрім перенесеного двічі IM та наявного ЦД 2-го типу, у пацієнтів обох груп спостереження з одно- та кількасудинним ураженням КА зустрічалась практично $з$ однаковим відсотковим числом. Також спостерігались гендерні та вікові розбіжності: прогресування стабільної IXC з більшою частотою виявляли у чоловіків $(84,2 \%)$.

За час спостереження проводили моніторинг таких кардіальних подій: частоти госпіталізацій 3 приводу загострення стенокардії; повторної ангіопластики із стентуванням КА, в тому числі і з приводу рестенозів; кількості аорто-коронарних шунтів (АКШ); чисельності нефатальних IM та смертей від серцево-судинних причин [15].

ВЕМ проводили на велоергометрі моделі «Кардіо+» МНДИ, 944150.001РЕ (Україна) за східцеподібною методикою О. Й. Жарінова [6].

Вміст ЕТ-1 у сироватці крові визначали за допомогою двохетапного імуноферментного багатоступеневого аналізу з використанням наборів "Віоmedica" (BI-20052, Австрія), ФНП- $\alpha$ - набором реагентів «ProCon TNF-alpha» (ProCon, Російська Федерація) на аналізаторі «Stat-Fax 210200» фірми Awareness Technology, Inc (США). Кількість СРБ у сироватці крові визначали методом латексної аглютинації, використовуючи набір реактивів «Гранум» (Україна).

Для об'єктивної оцінки ступеня достовірності результатів дослідження застосовували варіаційно-статистичний метод аналізу отриманих результатів на персональному комп'ютері Pentium II iз використанням пакета статистичних програм «Statistica 8.0» і пакета статистичних функцій «Microsoft Excel». Параметричні дані подавали як $\mathrm{M} \pm \mathrm{m}$.

Результати дослідження та їх обговорення. При аналізі клінічних особливостей перебігу захворювання до лікування виявлено, що напад стенокардії у пацієнтів ОГ і КГ маніфестували больовим синдромом 3 переважанням пекучого характеру - у $65,5 \%$ та 66,1 \% хворих, відповідно, стискаючого - у 
24,1 \% та 21,0 \% пацієнтів, а в 10,4 \% і 12,9 \% - ріжучого. Загрудинний біль супроводжувався відчуттям тяжкості у $82,8 \%$ та 69,4 \% хворих ОГ та КГ, відповідно, стисненням за грудиною - у 86,2 \% та 79,0 \% пацієнтів, задишкою - у 74,1 \% та $64,5 \%$ осіб обох груп спостереження і відчуттям посиленого серцебиття - у 86,2 \% та 85,5\% досліджуваних ОГ і КГ. Часом пацієнти відмічали появу больового синдрому різних характерів.

Інтенсивність больового синдрому в пацієнтів обох груп з супутнім ЦД була менш вираженою. Їх частіше турбували задишка та відчуття посиленого серцебиття із перебоями в роботі серця.

У пацієнтів ОГ із ураженою одною КА типовий коронарний ангінальний синдром вимагав додаткового прийому $12,53 \pm 0,69$ таблетки нітрогліцерину на тиждень. Середня ЧСС становила $82,93 \pm 2,25$ уд/хв, що на 19,8 \% було більше від показника здорових $(\mathrm{p}<0,05)$. Рівень АТ систолічного складав $165,00 \pm 19,73$ мм рт.ст.

Через 6 місяців від початку лікування 2 пацієнти ОГ із встановленим одним стентом у КА потребували додаткового вживання $1,50 \pm 0,71$ таблетки нітрогліцерину на тиждень $(\mathrm{p}<0,05)$. Пацієнтів зрідка турбували дискомфортні відчуття за грудиною, що провокувалися надмірним фізичним та психоемоційним навантаженням. В анамнезі обидва перенесли IM та мають супутню АГ. До кінця ж дослідження такої потреби не виникало в жодного 3 пацієнтів даної підгрупи.

На визначених етапах спостереження (через 6 та 12 місяців, відповідно) відмічалося стійке утримання цільових рівнів ЧСС - 66,13 22,20 та $65,20 \pm 1,37$ уд/хв. Терапія івабрадином сприяла досягненню цільових рівнів АТ протягом 12 місяців спостереження: через 6 і 12 місяців, відповідно, $124,67 \pm 3,99$ та $123,33 \pm 3,09$ мм рт. ст. При виконанні ВEM через 6 і 12 місяців у 12-ти та 14-ти хворих ОГ із встановленим одним стентом при навантаженні на 125 Вт та у 3-ох і 1-го на 75 - 100 Вт на фоні підвищених рівнів АТ до 170/110 мм рт. ст. виникали типові ЕКГ-ознаки ішемії міокарда та дискомфортні відчуття за грудиною, що свідчило про наявність I та II ФК стенокардії напруги, відповідно.

Потреба в додатковому прийомі нітрогліцерину до лікування у пацієнтів ОГ з ураженням кількох КА становила $14,01 \pm 0,29$ таблетки на тиждень. У подальшому після ЧКВ відмічалася стабільна позитивна динаміка перебігу захворювання. Через 6 місяців спостереження така потреба була у 5-ти, а в кінці спостереження - у 4-х досліджуваних та вимагала прийому $1,80 \pm 0,45$ i $1,75 \pm 0,50$ таблетки/тиждень, відповідно. Загрудинний дискомфорт у даних хворих був слабовираженим і значно зменшився за тривалістю, провокувався стресами та надмірною фізичною працею. 3 анамнезу встановлено, що дані паціснти хворіли більше 7-ми років і мали супутні ЦД та постінфарктний кардіосклероз, що в свою чергу доказує значимість цих ФР стабільної IXC.

У цієї підгрупи пацієнтів, аналогічно пацієнтам ОГ із стентованою однією КА, відмічалося стійке зниження і утримання цільових рівнів ЧСС та АТ протягом всього періоду спостереження. Динаміка
ЧСС була наступною: до стентування КА - 91,30 $\pm 3,83$ уд/хв., через 6 та 12 місяців $68,19 \pm 2,66$ та 66,37 $\pm 2,08$ уд/хв, відповідно, $(\mathrm{p}<0,05)$. У часовому проміжку фіксували такі величини АТ систолічного: до лікування $169,65 \pm 10,54$ мм рт.ст, через 6 та 12 місяців терапії - 125,35 $\pm 3,68$ мм рт.ст та $124,19 \pm 3,08$ мм рт.ст. (всі $\mathrm{p}<0,05)$.

Через 6 місяців лікування встановлено I та II ФК стенокардії напруги у 33 та 10 хворих, відповідно. У подальшому результати ВЕМ вказували на збільшення кількості обстежуваних з І ФК та водночас зменшення із II ФК стенокардії напруги. Таким чином, на 12-му місяці спостереження кількість пацієнтів із І ФК зросла до 38 хворих, а із II ФК зменшилась до 5, відповідно.

Пацієнти КГ 3 односудинним коронарним ураженням до лікування відчували додаткову потребу у застосуванні короткодіючих нітратів у кількості $11,81 \pm 0,35$ таблетки на тиждень. Через 6 та 12 місяців лікування потреба в додатковому прийомі нітрогліцерину була в 4-ьох пацієнтів і становила $1,75 \pm 0,50$ та $2,0 \pm 0,82$ таблетки/тиждень, відповідно $(\mathrm{p}<0,05)$. Причому наприкінці дослідження в одного 3 пацієнтів 3 перенесеним IM, діагностованою дисліпідемію та надлишковою масою тіла поріг чутливості до ангінозних болей був дещо нижчим, за весь період спостереження хворий піддавався постійному фізичному та психоемоційному навантаженню, продовжував палити до 5-ти цигарок на добу.

У пацієнтів КГ з односудинним коронарним ураженням ЧСС до лікування становила $82,4 \pm 2,96$ уд/хв., через 6 і 12 місяців спостереження на фоні максимально можливої дози бісопрололу ЧСС знизи-

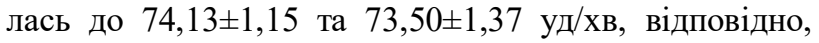
$(\mathrm{p}<0,05)$. Досягти цільового рівня ЧСС та утримати на довготривалий період піддавалось важко через властивість бісопрололу також і знижувати рівень АТ. На момент поступлення у хворих даної підгрупи АТ систолічний становив $163,75 \pm 16,88$ мм рт.ст., через 6 i 12 місяців терапії рівень його знизився до $122,19 \pm 2,56$ та $118,13 \pm 3,10$ мм рт.ст. Через 6 місяців спостереження у 10-ти хворих даної підгрупи встановлений I ФК, а в решту 6-ти - II ФК стенокардії напруги. На кінцевому етапі спостереження в 11 пацієнтів діагностовано I-й і у 5-ти II-й ФК стенокардії напруги.

Потреба в додатковому прийомі нітрогліцерину до малоінвазивного втручання на кількох КА на фоні застосування БТ становила $13,89 \pm 0,24$ таблетки на тиждень, а через 6 місяців терапії виникла в 7-ми хворих i вимагала прийому $1,86 \pm 0,69$ таблетки/тиждень. На завершальному етапі спостереження така потреба була у 8-ми хворих і становила 4,63 $\pm 2,83$ таблетки/тиждень. На початку дослідження у хворих КГ з кількасудинним коронарним ураженням ЧСС становила 89,6 $\pm 1,62$ уд/хв. У динаміці даний показник мав тенденцію до зменшення, проте цільових рівнів його значення досягти не вдалося i

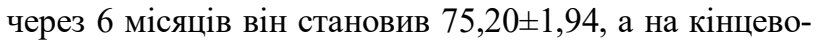

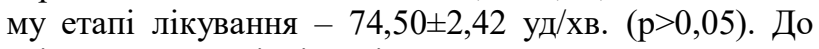
здійснення кардіохірургічного та медикаментозного лікування у пацієнтів даної підгрупи рівень АТ систолічного становив 168,26 $\pm 11,41$ мм рт.ст, через 6 та 
12 місяців знизився до $122,07 \pm 2,49$ та $118,26 \pm 3,02$ мм рт.ст., відповідно, що в свою чергу унеможливлювало збільшування дози бісопрололу. Через 6 місяців лікування дані ВЕМ підтвердили наявність стенокардії напруги I та II ФК у 29 та 17 хворих, відповідно, до 12-го місяця - у 30-ти пацієнтів встановлено I ФК стенокардії напруги, в 13-ти II ФК та у 3-х - III ФК стабільної IXC.

Кількість та структура кардіальних подій протягом 12 місяців спостереження у хворих обох груп відрізнялись. Так, у пацієнтів ОГ було зареєстровано 10 (17,2 \%) кардіальних подій (з приводу наявних дискомфортних відчуттів за грудиною), у КГ 23 (37,1 \%) кардіальні події (на завершальному етапі дослідження у 2-ох хворих встановлено III ФК сенокардії напруги, проведено ангіопластику із повторним стентуванням КА; в одного виник нефатальний IM із повторним ЧКВ; 3 госпіталізації та 16 звернень за медичною допомогою 3 приводу дестабілізації стенокардії напруги). Слід відмітити, що кардіальні події, котрі стали причиною повторної ангіопластики зі стентуванням КА та нефатальний IM виникли у пацієнтів із кількасудинним ураженням та супутніми ЦД, ожирінням та дисліпідемією. Смерті від серцевосудинних причин, зростання ФК стенокардії до IV класу; АКШ та рестенозів у стентах за час спостереження не відмічено [14].

Різноманітність та частота кардіальних ускладнень зростали 3 8-го місяця лікування, що пояснюється прогресуванням атеросклерозу вінцевих артерій.

Таким чином, додаткове застосування до БТ інгібітора If-каналів синусового вузла хворими на стабільну IXC після ангіопластики зі стентуванням КА забезпечує ефективний лікувальний ефект на довготривалий період.

Під впливом івабрадину у пацієнтів після стентування однієї КА дисфункція ендотелію достовірно зменшилась (табл. 1). Через 6 і 12 місяців після лікування вміст ЕТ-1 у сироватці крові знизився на $26,1 \%$ і $36,7 \%$, відповідно $(p<0,05)$, у порівнянні 3 показниками до лікування. Наприкінці дослідження рівень ЕТ-1 максимально наблизився до величини такого ж показника здорових.

Вплив івабрадину на вміст ЕТ-1, ФНП-а і СРБ у хворих на стабільну ІХС до і після стентування КА

\begin{tabular}{|c|c|c|c|c|c|c|c|}
\hline \multirow{4}{*}{ Показник } & \multirow{3}{*}{$\begin{array}{l}\text { Здорові, } \\
\mathrm{n}=15\end{array}$} & \multicolumn{2}{|c|}{ У момент госпіталізації } & \multicolumn{4}{|c|}{ Після лікування } \\
\hline & & \multirow{2}{*}{$\begin{array}{c}\text { Ураження } \\
\text { однієї КА, } \\
\mathrm{n}=15\end{array}$} & \multirow{2}{*}{$\begin{array}{c}\text { Кількасудинне } \\
\text { ураження КА, } \\
\text { n }=43\end{array}$} & \multicolumn{2}{|c|}{ Стентування однієї КА } & \multicolumn{2}{|c|}{$\begin{array}{c}\text { Стентування кількох } \\
\text { КА } \\
\end{array}$} \\
\hline & & & & $\begin{array}{c}6 \text { місяців, } \\
\mathrm{n}=15\end{array}$ & $\begin{array}{c}12 \\
\text { місяців, } \\
\mathrm{n}=15\end{array}$ & $\begin{array}{c}6 \text { місяців, } \\
\mathrm{n}=43\end{array}$ & $\begin{array}{c}12 \text { місяців, } \\
\mathrm{n}=43\end{array}$ \\
\hline & 1 & 2 & 3 & 4 & 5 & 6 & 7 \\
\hline $\begin{array}{l}\text { ЕT-1, } \\
\text { нг/мЛ, } \\
\text { p, } \\
\Delta \%\end{array}$ & $5,41 \pm 0,24$ & $\begin{array}{l}8,61 \pm 0,08 \\
\text { p1-2<0,05 }\end{array}$ & $\begin{array}{l}9,48 \pm 0,18 \\
\text { p1-3<0,05 } \\
\text { p2-3<0,05 }\end{array}$ & $\begin{array}{c}6,36 \pm 0,10 \\
\text { p1-4<0,05 } \\
\text { p2-4<0,05 } \\
26,1 \%\end{array}$ & $\begin{array}{c}5,45 \pm 0,09 \\
\text { p1-5>0,05 } \\
\text { p2-5<0,05 } \\
\text { p4-5<0,05 } \\
36,7 \%\end{array}$ & $\begin{array}{c}7,15 \pm 0,13 \\
\text { p1-6<0,05 } \\
\text { p3-6<0,05 } \\
24,6 \%\end{array}$ & $\begin{array}{c}6,04 \pm 0,12 \\
\text { p1-7<0,05 } \\
\text { p3-7<0,05 } \\
\text { p6-7<0,05 } \\
36,3 \%\end{array}$ \\
\hline $\begin{array}{l}\text { ФНП-а, } \\
\Pi г / \text { мл, } \\
\mathrm{p}, \\
\Delta \% ;\end{array}$ & $25,60 \pm 2,37$ & $\begin{array}{l}109,29 \pm 5,55 \\
\text { p1-2<0,05 }\end{array}$ & $\begin{array}{l}129,23 \pm 2,97 \\
\text { p1-3<0,05 } \\
\text { p2-3<0,05 }\end{array}$ & $\begin{array}{c}58,20 \pm 2,01 \\
\text { p1-4<0,05 } \\
\text { p2-4<0,05 } \\
46,7 \%\end{array}$ & $\begin{array}{c}27,07 \pm 1,91 \\
\text { p1-5 }>0,05 \\
\text { p2-5<0,05 } \\
\text { p4-5<0,05 } \\
75,2 \% \\
\end{array}$ & $\begin{array}{c}71,19 \pm 2,06 \\
\text { p1-6<0,05 } \\
\text { p3-6<0,05 } \\
44,9 \% \\
\end{array}$ & $\begin{array}{c}36,91 \pm 1,52 \\
\text { p1-7<0,05 } \\
\text { p3-7<0,05 } \\
\text { p6-7<0,05 } \\
71,4 \%\end{array}$ \\
\hline $\begin{array}{l}\text { СРБ, г/л, } \\
\text { p, }\end{array}$ & $2,40 \pm 0,18$ & $\begin{array}{l}8,93 \pm 0,46 \\
\text { p1-2<0,05 }\end{array}$ & $\begin{array}{l}11,84 \pm 1,02 \\
\text { p1-3<0,05 } \\
\text { p2-3<0,05 }\end{array}$ & $\begin{array}{c}4,09 \pm 0,24 \\
\text { p1-4<0,05 } \\
\text { p2-4<0,05 } \\
54,2 \%\end{array}$ & $\begin{array}{c}2,62 \pm 0,13 \\
\text { p1-5<0,05 } \\
\text { p2-5<0,05 } \\
\text { p4-5<0,05 } \\
70,7 \%\end{array}$ & $\begin{array}{c}5,47 \pm 0,13 \\
\text { p1-6<0,05 } \\
\text { p3-6<0,05 } \\
53,8 \%\end{array}$ & $\begin{array}{c}3,91 \pm 0,16 \\
\text { p1-7<0,05 } \\
\text { p3-7<0,05 } \\
\text { p6-7<0,05 } \\
67,0 \%\end{array}$ \\
\hline
\end{tabular}

Примітка: представлені у \% показники - це по відношенню до цифр у момент госпіталізації

Тривалий терапевтичний ефект стосувався також показників імунозапальної реакції: через 6 місяців лікування показники ФНП- $\alpha$ і СРБ у пацієнтів із стентованою одною КА знизилися на $46,7 \%$ i $54,2 \%(\mathrm{p}<0,05)$, відповідно. Через 12 місяців лікування рівень ФНП- $\alpha$ зменшився у 4 рази і становив $27,07 \pm 1,91$ пг/мл та був максимально наближеним до показника здорових, як і рівень СРБ (на завершальному етапі спостереження знизився у 3,4 раза від моменту поступлення).

Івабрадин у хворих із стентованими 2-ма і більше КА знижував вміст ЕТ-1 у сироватці крові через
6 та 12 місяців на 24,6 і 36,3\%, відповідно (p<0,05). Аналогічні зміни стосувались показників імунозапальної реакції: через 6 місяців лікування показники ФНП- $\alpha$ і СРБ у пацієнтів із стентованими кількома КА знизилися на 44,9\% та 53,8 \% $(\mathrm{p}<0,05)$, через 12 місяців на 71,4\% та 67,0\%, відповідно.

У пацієнтів КГ після стентування однієї КА показники імунного запалення й рівень ЕТ-1 знизились $(\mathrm{p}<0,05)$, як і у хворих ОГ, але менш виражено (табл. 2). Так, через 12 місяців після стентування вміст ЕТ-1 у сироватці крові був більшим у 1,4 раза, 
ФНП- $\alpha$ - у 2,9 раза, СРБ - в 1,9 раза, ніж у хворих, що приймали івабрадин.

Слід відмітити, що показники ЕД та імунозапальної активації у пацієнтів даної підгрупи знижу- вались достовірно в перші 6 місяців лікування, чого не відмічалося у другому півріччі.

Вплив базової терапії на вміст ЕТ-1, ФНП-а і СРБ у хворих на стабільну ІХС до і після стентування КА

\begin{tabular}{|c|c|c|c|c|c|c|c|}
\hline \multirow{4}{*}{ Показник } & \multirow[b]{3}{*}{$\begin{array}{c}\text { Здорові, } \\
\mathrm{n}=15\end{array}$} & \multirow{2}{*}{\multicolumn{2}{|c|}{ У момент госпіталізації }} & \multicolumn{4}{|c|}{ Після лікування } \\
\hline & & & & \multicolumn{2}{|c|}{ Стентування однієї КА } & \multicolumn{2}{|c|}{ Стентування кількох КА } \\
\hline & & $\begin{array}{c}\text { Ураження } \\
\text { однієї КА, } \\
\text { n }=16\end{array}$ & $\begin{array}{c}\text { Кількасуди } \\
\text { нне } \\
\text { ураження } \\
\text { КА, } \mathrm{n}=46 \\
\end{array}$ & $\begin{array}{c}6 \text { місяців, } \\
\mathrm{n}=16\end{array}$ & $\begin{array}{c}12 \text { місяців, } \\
\mathrm{n}=16\end{array}$ & $\begin{array}{c}6 \text { місяців, } \\
n=46\end{array}$ & $\begin{array}{c}12 \text { місяців, } \\
\mathrm{n}=46\end{array}$ \\
\hline & 1 & 2 & 3 & 4 & 5 & 6 & 7 \\
\hline $\begin{array}{l}\text { ЕТ-1, } \\
\text { нг/мл, } \\
\mathrm{p}, \\
\Delta \%\end{array}$ & $5,41 \pm 0,24$ & $\begin{array}{l}8,51 \pm 0,19 \\
\text { p1-2<0,05 }\end{array}$ & $\begin{array}{l}9,33 \pm 0,21 \\
\text { p1-3<0,05 } \\
\text { p2-3<0,05 }\end{array}$ & $\begin{array}{c}7,94 \pm 0,10 \\
\text { p1-4<0,05 } \\
\text { p2-4<0,05 } \\
6,7 \% \\
\end{array}$ & $\begin{array}{c}7,64 \pm 0,15 \\
\text { p1-5<0,05 } \\
\text { p2-5<0,05 } \\
\text { p4-5<0,05 } \\
10,2 \%\end{array}$ & $\begin{array}{c}8,91 \pm 0,15 \\
\text { p1-6<0,05 } \\
\text { p3-6<0,05 } \\
4,5 \%\end{array}$ & $\begin{array}{c}8,82 \pm 0,36 \\
\text { p1-7<0,05 } \\
\text { p3-7<0,05 } \\
\text { p6-7>0,05 } \\
5,5 \%\end{array}$ \\
\hline $\begin{array}{l}\text { ФНП-а, } \\
\text { Пг/мл, } \\
\mathrm{p}, \\
\Delta \%\end{array}$ & $25,60 \pm 2,37$ & $\begin{array}{c}108,11 \pm 3,5 \\
8 \\
\text { p1-2<0,05 }\end{array}$ & $\begin{array}{c}126,31 \pm 4,82 \\
\text { p1-3<0,05 } \\
\text { p2-3<0,05 }\end{array}$ & $\begin{array}{c}81,88 \pm 1,86 \\
\text { p1-4<0,05 } \\
\text { p2-4<0,05 } \\
24,3 \%\end{array}$ & $\begin{array}{c}79,13 \pm 1,50 \\
\text { p1-5<0,05 } \\
\text { p2-5<0,05 } \\
\text { p4-5<0,05 } \\
26,8 \%\end{array}$ & $\begin{array}{c}98,41 \pm 2,9 \\
0 \\
\text { p1 }-6<0,05 \\
\text { p3-6<0,05 } \\
22,1 \% \\
\end{array}$ & $\begin{array}{c}96,72 \pm 5,30 \\
\text { p1-7<0,05 } \\
\text { p3-7<0,05 } \\
\text { p6-7>0,05 } \\
23,3 \%\end{array}$ \\
\hline $\begin{array}{l}\text { СРБ, Г/л, } \\
\mathrm{p}, \\
\Delta \%\end{array}$ & $2,40 \pm 0,18$ & $\begin{array}{l}8,71 \pm 0,42 \\
\text { p1-2<0,05 }\end{array}$ & $\begin{array}{l}11,02 \pm 0,91 \\
\text { p1-3<0,05 } \\
\text { p2-3<0,05 }\end{array}$ & $\begin{array}{c}5,38 \pm 0,18 \\
\text { p1-4<0,05 } \\
\text { p2-4<0,05 } \\
\\
38,2 \% \\
\end{array}$ & $\begin{array}{c}4,95 \pm 0,17 \\
\text { p1-5<0,05 } \\
\text { p2-5<0,05 } \\
\text { p4-5<0,05 } \\
43,2 \%\end{array}$ & $\begin{array}{c}7,02 \pm 0,25 \\
\text { p1-6<0,05 } \\
\text { p3-6<0,05 } \\
36,3 \% \\
\end{array}$ & $\begin{array}{c}6,73 \pm 1,19 \\
\text { p1-7<0,05 } \\
\text { p3-7<0,05 } \\
\text { p6-7<0,05 } \\
38,9 \%\end{array}$ \\
\hline
\end{tabular}

Примітка: представлені у \% показники - це по відношенню до цифр у момент госпіталізації

Порівнявши показники ЕД та системної імунозапальної активності у пацієнтів ОГ та КГ у часовому проміжку (табл. 3), видно, що зниження вмісту ЕT-1 до 6-го місяця лікування відзначалося в обох групах спостереження, але 3 більшим відсотковим значенням у хворих ОГ ( $<<0,05)$. На 12-й місяць лікування вміст ЕТ-1 продовжував достовірно знижуватись у пацієнтів ОГ і максимально наблизився до показника здорових, у той час як у хворих КГ вели- чина ЕT-1 практично не відрізнялася від піврічного показника лікування ( $>0,05)$. Показники імунозапальної реакції та системного запалення - ФНП-а та СРБ достовірно знижувалися на 6-й та 12-й місяці лікування у пацієнтів, котрі приймали івабрадин, а у хворих на базовій терапії достовірне зниження даних показників було тільки до 6-го місяця лікування $(\mathrm{p}<0,05)$.

Таблиця 3

Порівняльна характеристика динаміки показників ЕД та системної імунозапальної активності у хворих після стентування КА

\begin{tabular}{|c|c|c|c|c|c|c|c|c|}
\hline \multirow{4}{*}{ Показник } & \multicolumn{8}{|c|}{ Після лікування } \\
\hline & \multicolumn{2}{|c|}{6 місяців (ОГ) } & \multicolumn{2}{|c|}{12 місяців (ОГ) } & \multicolumn{2}{|c|}{6 місяців (КГ) } & \multicolumn{2}{|c|}{12 місяців (КГ) } \\
\hline & $\begin{array}{l}1 \mathrm{KA}, \\
\mathrm{n}=15\end{array}$ & $\begin{array}{l}2 \text { KA, } \\
\mathrm{n}=43\end{array}$ & $\begin{array}{l}1 \mathrm{KA}, \\
\mathrm{n}=15\end{array}$ & $\begin{array}{l}2 \mathrm{KA}, \\
\mathrm{n}=43\end{array}$ & $\begin{array}{l}1 \mathrm{KA}, \\
\mathrm{n}=16\end{array}$ & $\begin{array}{l}2 \mathrm{KA}, \\
\mathrm{n}=46\end{array}$ & $\begin{array}{l}1 \mathrm{KA}, \\
\mathrm{n}=16\end{array}$ & $\begin{array}{l}2 \mathrm{KA}, \\
\mathrm{n}=46\end{array}$ \\
\hline & 1 & 2 & 3 & 4 & 5 & 6 & 7 & 8 \\
\hline \multirow{2}{*}{$\begin{array}{l}\text { ЕТ-1, } \\
\text { нг/мЛ, }\end{array}$} & $6,36 \pm 0,10$ & $7,15 \pm 0,13$ & $5,45 \pm 0,09$ & $6,04 \pm 0,12$ & $7,94 \pm 0,10$ & $8,91 \pm 0,15$ & $7,64 \pm 0,15$ & $8,82 \pm 0,36$ \\
\hline & \multicolumn{2}{|c|}{$\begin{array}{l}\text { p1-3<0,05;14,3\% } \\
\text { p2-4<0,05;15,2\% }\end{array}$} & \multicolumn{2}{|c|}{$\begin{array}{l}\text { p3-7<0,05; } 28,7 \% \\
\text { p4-8<0,05; } 31,5 \%\end{array}$} & \multicolumn{2}{|c|}{$\begin{array}{l}\text { p1-5<0,05; } 19,9 \% \\
\text { p2-6<0,05; } 19,8 \%\end{array}$} & \multicolumn{2}{|c|}{$\begin{array}{l}\mathrm{p} 5-7>0,05 ; 4,2 \% \\
\text { p6-8 }>0,05 ; 1,0 \%\end{array}$} \\
\hline \multirow{2}{*}{$\begin{array}{l}\text { ФНП-а, } \\
\text { Пг/мл, } \\
\text { p, } \Delta \%\end{array}$} & $58,20 \pm 2,01$ & $71,19 \pm 2,06$ & $27,07 \pm 1,91$ & $36,91 \pm 1,52$ & $81,88 \pm 1,86$ & $98,41 \pm 2,90$ & $79,13 \pm 1,50$ & $96,72 \pm 5,30$ \\
\hline & \multicolumn{2}{|c|}{$\begin{array}{l}\text { p1-3<0,05;53,5\% } \\
\text { p2-4<0,05; 48,2\% }\end{array}$} & \multicolumn{2}{|c|}{$\begin{array}{l}\text { p3-7<0,05;65,8\% } \\
\text { p4-8<0,05;61,8\% }\end{array}$} & \multicolumn{2}{|c|}{$\begin{array}{l}\text { p1-5<0,05;28,9\% } \\
\text { p2-6<0,05;27,7\% }\end{array}$} & \multicolumn{2}{|c|}{$\begin{array}{l}\text { p5-7>0,05;3,4\% } \\
\text { p6-8>0,05; } 1,7 \%\end{array}$} \\
\hline \multirow{2}{*}{$\begin{array}{l}\text { СРБ, г/л, } \\
\text { p, } \Delta \%\end{array}$} & $4,09 \pm 0,24$ & $5,47 \pm 0,13$ & $2,62 \pm 0,13$ & $3,91 \pm 0,16$ & $5,38 \pm 0,18$ & $7,02 \pm 0,25$ & $4,95 \pm 0,17$ & $6,73 \pm 1,19$ \\
\hline & \multicolumn{2}{|c|}{$\begin{array}{l}\text { p1-3<0,05; } 35,9 \% \\
\text { p2-4<0,05; } 19,2 \%\end{array}$} & \multicolumn{2}{|c|}{$\begin{array}{l}\text { p3-7<0,05; } 47,1 \% \\
\text { p4-8<0,05; } 41,9 \%\end{array}$} & \multicolumn{2}{|c|}{$\begin{array}{l}\text { p1-5<0,05;24,0\% } \\
\text { p2-6<0,05;22,1\% }\end{array}$} & \multicolumn{2}{|c|}{$\begin{array}{c}\text { p5-7<0,05; 7,4\% } \\
\text { p6-8>0,05\%; 4,1\% }\end{array}$} \\
\hline
\end{tabular}


Отже, у відновлювальному періоді після стентування КА лікувальні заходи у хворих на стабільну IXC першочергово повинні передбачати корекцію ФР (відмову від тютюнопаління, дотримання гіполіпідемічної дієти, зменшення маси тіла в пацієнтів з ожирінням, контролювання рівнів АТ, адекватне лікування ЦД, контрольоване дозоване фізичне навантаження та усунення психологічних чинників).

Івабрадин у хворих на стабільну IXC на фоні базового лікування стенокардії зменшує частоту й інтенсивність клінічних проявів стабільної IXC 3 мінімальним додатковим застосуванням короткодіючих нітратів. Найменше число нападів стенокардії після ЧКВ досягнуто у пацієнтів, які приймали івабрадин. Аналогічно нашому дослідженню досягнення цільових рівнів ЧСС після втручання у хворих незалежно від кількості уражених КА було у групі івабрадину, що підтверджує результати досліджень ASSOCIATE та BEAUTIFUL, які засвідчили, що івабрадин показаний при перебігу стенокардії напруги 3 недостатньо контрольованою ЧСС ( $\geq 70$ уд./хв.) [8, 14].

\section{Висновки:}

1. Доповнення базового лікування стабільної IXC івабрадином сприяє стабільній позитивній динаміці клінічної картини захворювання протягом 12 місяців 3 досягненням та утриманням цільових рівнів ЧСС без впливу на величини АТ, що дозволяе його застосування пацієнтам без супутньої АГ.

2. Івабрадин нормалізує функцію ендотелію, імунозапальні процеси у пацієнтів із стабільною IXC після стентування КА.

\section{References:}

1. Bazylevych AIa. Ohliad novyn Konhresu Yevropeiskoho tovarystva kardiolohiv. Liky Ukrainy. 2014; 7-8(183-184):34-41.

2. Vynohradov OO. Struktura y funktsii endoteliiu: istorychnyi aspekt problemy. Visnyk Luhanskoho natsionalnoho universytetu imeni Tarasa Shevchenka. 2013; 6(265); Ch.II.: 72-80.

3. Havrysh OS, Krychkevych VA. Morfolohichni osoblyvosti ishemizovanykh ta pozaishemizovanykh zon miokarda $\mathrm{V}$ patsiientiv $\mathrm{z}$ khronichnoiu ishemichnoiu khvoroboiu sertsia. Ukrainskyi kardiolohichnyi zhurnal. 2015; 6:44-52.

4. Handziuk VA. Analiz zakhvoriuvanosti na ishemichnu khvorobu sertsia v Ukraini. Ukr. kardiol. zhurnal. 2014; 3:45-52.

5. Horbas IM. Ishemichna khvoroba sertsia epidemiolohiia i statystyka. Kardiolohiia. Revmatolohiia. Kardiokhirurhiia. 2015; 3/1:15-21.

6. Zharinov OI, Kuts VO, Tkhor NV. Navantazhuvalni proby v kardiolohii. Medytsyna svitu. 2006. P.89.

7. Kovalenko OM, Rodionova VV Korektsiia endotelialnoi dysfunktsii $\mathrm{V}$ terapevtychnii stratehii sertsevo-sudynnoi patolohii. Kardyolohyia: ot nauky k praktyke. 2016; 2(21):31-38.

8. Koshlia VI, Cherniak VO. Zastosuvannia ivabradynu v likuvanni khvorykh na stenokardiiu napruzhennia. Ukrainskyi kardiolohichnyi zhurnal. 2011; 1:138.
9. Kupnovytska IH, Romanyshyn NM. Klinichni osoblyvosti perebihu ta pokaznyky endotelialnoi funktsii i systemnoi imunozapalnoi reaktsii $u$ khvorykh na stabilnu ishemichnu khvorobu sertsia zalezhno vid kilkosti urazhenykh koronarnykh arterii. Arkhiv klinichnoi medytsyny. 2019; 1(25):12-17.

10. Prasolov AV, Kniazeva LA, Lykov VF. Pokazately ymmunnoho vospalenyia, ryhydnost sosudystoi stenky u bolnokh stabylnoi stenokardyei napriazhenyia na fone terapyy bysoprololom. Kardyolohyia y serdechno-sosudystaia khyrurhyia. 2011; 4(4):37-40.

11. Tomylova DY, Biazrova FF, Buza VV. Rol markerov vospalenyia $\mathrm{v}$ otsenke prohnoza $\mathrm{u}$ patsyentov so stabylnoi formoi yshemycheskoi bolezny serdtsa posle koronarnoho stentyrovanyia. Kardyolohyia. 2015; 55(11):88-93.

12. Eapen DJ, Manocha P, Patel RS et al. Aggregate risk score based on markers of inflammation, cell stress, and coagulation is an independent predictor of adverse cardiovascular outcomes. J Am Coll Cardiol. 2013; 62(4):329-337. doi: 10.1016/j.jacc.2013.03.072.

13. Fang C. Underestimating Medical Therapy for Coronary Disease Again. Engl J Med. 2011; 364:1671-73.

14. Fox K, Komajda M. Ford I. et al. Effect of ivabradine in patients with left-ventricular systolic dysfunction: a pooled analysis of individual patient data from the BEAUTIFUL and SHIFT trials Eur. J. Heart Fail 2013; 34(29):2263-2270.

15. Kupnovytska I, Romanyshyn N. Evaluation of sinus node if-channel inhibitor effect in patients with stable coronary artery disease after surgical myocardial revascularization. The Pharma Innovation Journal 2020; 9(2):46-51.

16. Sianos G, Morel MA, Kappetein AP, Morice MC, Colombo A, Dawkins K, et al. The SYNTAX Score: an angiographic tool grading the complexity of coronary artery disease. EuroIntervention. 2005; 1(2):219227.

\section{УДК 616-08+615.22+616.12-005.4+616.12-089 \\ ВЛИЯНИЕ ИНГИБИТОРОВ ИЕ-КАНАЛОВ СИНУСОВОГО УЗЛА НА ТЕЧЕНИЕ СТА- БИЛЬНОЙ ИБС И НЕЙРОГУМОРАЛЬНОЙ РЕГУЛЯЦИИ СОСУДОВ У БОЛЬНЫХ ПОСЛЕ ВНУТРИСОСУДИСТОЙ КОРОНАРНОЙ АНГИОПЛАСТИКИ}

\section{И.Г. Купновицкая, Н.М. Романишин}

Ивано-Франковский национальньй медицинский университет, кафедра клинической фармакологии и фармакотерапии, 2. Ивано-Франковск, Украина, ORCID ID: 0000-0002-0243-2638,

e-mail: neliaromanyshyn@gmail.com

Резюме. Ежегодно заболевания сердечнососудистой системы обусловливают 4,3 млн. смертей в Европе, что составляет $48 \%$ от общей смертности. Около половины случаев летальности из них приходится на ишемическую болезнь сердца (ИБС). На 
сегодня известно, что в патогенезе ИБС важное место занимают эндотелиальная дисфункция (ЭД), оксидантный стресс, дислипидемия, системная иммуновоспалительная активация. Воспалительные процессы играют важную роль в процессе формирования как самой атеросклеротической бляшки, так и повреждения нестабильной атеромы с последующей тромботической окклюзией и развитием сердечнососудистых осложнений. Целью исследования было изучить влияние ивабрадина на клиническое течение заболевания, эндотелиальную функцию и показатели аутоиммунного ответа организма больных стабильной ИБС после реваскуляризации миокарда в течении 12 месяцев лечения. Объектом исследования избраны 120 больных стабильной ИБС: стенокардией напряжения функционального класса (ФК) III с сердечной недостаточностью (СН) IIA ФК III с сохраненной фракцией выброса левого желудочка (ФВ ЛЖ), которым проводили стентирование КА. Обследуемые больные рандомизированы по количеству пораженных коронарных артерий (КА) способом лечения. Ивабрадин способствует положительной достоверной динамике уровня эндотелина-1 (ЭТ-1) в течение наблюдения у пациентов со стабильной ИБС после комплексного кардиохирургического и медикаментозного лечения. Показатели аутоиммунной реакции и системного воспаления - содержание фактора некроза опухолей-а (ФНО-а) и С-реактивного белка (СРБ) в сыворотке крови достоверно снижались на 6й и 12-й месяцы после лечения в отличие от контрольной группы (базовая терапия), где данные показатели были стабильными только к 6-му месяцу фармакотерапии $(\mathrm{p}<0,05)$.

Ключевые слова: ивабрадин, ишемия миокарда, коронарные артерии, стентирование, цитокины.

UDC 616-08+615.22+616.12-005.4+616.12-089

THE EFFECT OF THE SINUS NODE IF-CHANNEL INHIBITOR ON THE CLINICAL COURSE OF STABLE CORONARY ARTERY DISEASE AND NEUROHUMORAL REGULATION OF BLOOD VESSELS IN PATIENTS AFTER INTRAVENOUS CORONARY ANGIOGRAPHY

\author{
I.G. Kupnovytska, N.M. Romanyshyn
}

Ivano-Frankivsk National Medical University,
Department of Clinical Pharmacology and
Pharmacotherapy, Ivano-Frankivsk, Ukraine,
ORCID ID:0000-0002-0243-2638,
e-mail: neliaromanyshyn@gmail.com

Abstract. Cardiovascular diseases cause 4.3 million deaths in Europe every year, which accounts for $48 \%$ of all deaths. Coronary artery disease (CAD) accounts for approximately one-half of deaths attributable to cardiovascular diseases. Endothelial dysfunction (ED), oxidative stress, dyslipidemia, and systemic immune-inflammation activation are currently known to play an important role in the pathogenesis of CAD. The inflammatory processes play a significant role in both the formation of atherosclerotic plaque and the injury to unstable atheroma followed by thrombotic occlusion and the development of cardiovascular complications. The aim of the research was to study the effect of ivabradine on the clinical course of the disease, endothelial function and indicators of the body's immuneinflammatory response in patients with stable CAD after myocardial revascularization within 12 months of treatment. The study recruited 120 patients with chronic CAD, heart failure (HF) with preserved left ventricular (LV) ejection fraction (EF), who underwent coronary artery (CA) stenting. All the patients were randomized according to the number of the affected CA and the method of treatment. The addition of ivabradine to therapeutic complex for patients with stable CAD after CA stenting was found to significantly reduce and maintain target heart rate (HR) for long periods of time thereby improving QoL and exercise tolerance (ET), preventing complications, helping patients in returning to work. The lowest angina attack frequency after PCI was achieved in patients receiving ivabradine. Our study confirmed reaching target HR after intervention irrespective of the number of the affected CA in ivabradine group of patients as evidenced by the results of the ASSOCIATE and BEAUTIFUL trials which showed that ivabradine is indicated for treatment of stable angina and insufficiently controlled HR $(\geq 70 \mathrm{bpm})$. Ivabradine improves the clinical picture and neurohumoral status in patients who underwent intravascular coronary angioplasty irrespective of the number of the CA affected; it contributes to positive dynamic changes in endothelin-1 (ET-1), indicators of immune-inflammatory activity and systemic inflammatory response over a certain period in patients with stable CAD after combined cardiosurgical and therapeutic treatment. The reduction in ET- 1 level up to the $6^{\text {th }}$ month of treatment was observed in both groups; however, the percent value was greater in patients of the main group $(\mathrm{p}<0.05)$. On the $12^{\text {th }}$ month of treatment, ET-1 level continued to reduce significantly in patients of the main group and almost corresponded to that in healthy individuals. In contrast, in patients of the control group, the level of ET-1 continued to reduce moderately and almost did not differ from the first 6-month treatment indicator $(\mathrm{p}>0.05)$. The indicators of the immune-inflammatory response and systemic inflammation, namely tumor necrosis factor $(\mathrm{TNF}-\alpha)$ and $\mathrm{C}$-reactive protein (CRP), significantly reduced on the $6^{\text {th }}$ and $12^{\text {th }}$ months of treatment in patients, who received ivabradine. In patients, who underwent background therapy, a significant reduction in these indicators was observed till the $6^{\text {th }}$ month of treatment only $(p<0.05)$. The comparison of the immune-inflammatory response indicators on the $6^{\text {th }}$ month of treatment among patients of both groups revealed the reduction in TNF- $\alpha$ and CRP with a greater percent value in patients of the main group.

Keywords: ivabradine, myocardial ischemia, coronary arteries, stenting, cytokines. 